\title{
Fungicide Sensitivity of Pythium spp. Associated with Cavity Spot of Carrot in California and Michigan
}

Xiao Hong Lu, Department of Plant Pathology, Michigan State University, East Lansing 48824; R. Michael Davis, S. Livingston, and J. Nunez, Department of Plant Pathology, University of California, Davis 95616; and Jianjun J. Hao, Department of Plant Pathology, Michigan State University

\begin{abstract}
Lu, X. H., Davis, R. M., Livingston, S., Nunez, J., and Hao, J. J. 2012. Fungicide sensitivity of Pythium spp. associated with cavity spot of carrot in California and Michigan. Plant Dis. 96:384-388.

The identity of 172 isolates of Pythium spp. from cavity spot lesions on carrot produced in California and Michigan was determined, and their sensitivity to three fungicides was examined. Pythium violae accounted for $85 \%$ of California isolates, with $P$. irregulare, $P$. dissotocum (the first report as a carrot pathogen in the United States), P. ultimum, and $P$. sulcatum making the balance. $P$. sulcatum, $P$. sylvaticum, and $P$. intermedium were the most commonly recovered $(85 \%)$ species in Michigan; others from Michigan included P. intermedium, P. irregulare, and an unclassified strain, M2-05. On fungicide-amended media, $93 \%$ of isolates were sensitive to mefenoxam (inhibition of mycelial growth was $>60 \%$ at $10 \mu \mathrm{g}$ active ingredient [a.i.]/ml); however, two of

( $\leq 60 \%$ inhibition at $100 \mu \mathrm{g}$ a.i./ml); about half of the isolates of $P$ intermedium and $P$. sylvaticum and a single isolate of $P$. violae were highly or intermediately resistant to mefenoxam ( $>60 \%$ inhibition at $100 \mu \mathrm{g}$ a.i. $/ \mathrm{ml}$, or $\leq 60 \%$ inhibition at $10 \mu \mathrm{g}$ a.i./ml). $P$. dissotocum, $P$. irregulare, $P$. sulcatum, M2-05, and three of seven isolates of $P$. intermedium were insensitive to fluopicolide (effective concentrations for $50 \%$ growth inhibition $\left[\mathrm{EC}_{50}\right]$ were $>50 \mu \mathrm{g}$ a.i. $/ \mathrm{ml}$ ), while $P$. sylvaticum, $P$. ultimum, $P$. violae, and some isolates in $P$. intermedium were sensitive $\left(\mathrm{EC}_{50}<1 \mu \mathrm{g}\right.$ a.i./ml $)$. All isolates were sensitive to zoxamide $\left(\mathrm{EC}_{50}<1 \mu \mathrm{g}\right.$ a.i./ml). Sensitivity baselines of $P$. violae to zoxamide and fluopicolide were established.
\end{abstract} five isolates of $P$. irregulare from California were highly resistant
Carrot (Daucus carota L.) is planted on over 35,000 ha in the United States, with an approximate value of $\$ 600$ million (3). California and Michigan are the two largest carrot-producing states for the fresh market, accounting for $89 \%$ of U.S. production (5). Carrot cavity spot (CCS), an economically important soilborne disease, is one of the limiting factors in the production of high-quality roots (33). Disease symptoms are characterized by sunken elliptical lesions on the surface of the tap root. The lesions darken in color and increase in size as the disease progresses $(20,27,38)$.

Many Pythium spp. have been reported to cause CCS but the profile of species varies from region to region $(1,12,15,27)$. In Japan, Australia, certain European countries, and some regions of North America, the slow-growing species Pythium violae and $P$. sulcatum are the most important causal agents of CCS $(17,20,42)$, whereas the fast-growing species $P$. sylvaticum, $P$. ultimum, and $P$. intermedium are the most common species associated with CCS in Canada (2), Norway (19), and the United Kingdom (41). Other Pythium spp., including $P$. coloratum (14), P. rostratum (41), $P$. dissotocum (2), P. macrosporum (2,22), P. irregulare (20), and $P$. aphanidermatum (40), also have been associated with CCS. At least four Pythium spp. associated with CCS in California have been reported $(18,38)$ but the causal agents of CCS in Michigan have not been well documented (31).

Management of CCS is difficult. Crop rotation is often ineffective because Pythium spp. generally have broad host ranges $(12,13,21,32)$. Partial resistance to CCS is limited to a few carrot cultivars $(7,8,20)$, and minimizing the disease with irrigation management may moderate the disease to a small extent $(28,38)$. Most growers judiciously use fungicides to minimize the impact of CCS but the performance of fungicides has been variable. Metalaxyl or

Corresponding author: J. J. Hao, E-mail: jjhao@msu.edu

Accepted for publication 17 October 2011.

http://dx.doi.org/10.1094/PDIS-07-11-0562

(C) 2012 The American Phytopathological Society its enantiomer mefenoxam has long been used $(10,11,20)$ but its efficacy has been reduced by enhanced microbial degradation (15), reduced persistence of the chemical in soil (11), and emerging resistant pathogen populations (2,22). Zoxamide (FRAC Code 22), which is not currently registered for use on carrot, effectively inhibited in vitro mycelial growth of $P$. sulcatum, $P$. sylvaticum, and $P$. macrosporum in laboratory conditions, and provided significant and consistent control of CCS caused by P. sulcatum in greenhouse assays (22). However, the impact of zoxamide on other $P$ thium spp. remains unknown. In most states, the fungicide fluopicolide (FRAC Code 43) is registered for use on vegetables, except carrot. In general, fluopicolide effectively reduces the impact of diseases caused by oomycete pathogens, including some Pythium spp. (36), but no data are available for CCS control. Although both zoxamide and fluopicolide inhibit mitosis and cell division (4), the cellular targets differ and the spectrum might be different. Thus, zoxamide and fluopicolide represent new fungicides with the potential to manage CCS, and their registration for use on carrot in California and Michigan is anticipated. For these reasons, the objectives of this study were to identify the pathogen complex and determine the fungicide sensitivity of the pathogen complex of CCS in California and Michigan.

\section{Materials and Methods}

Isolation and identification of Pythium spp. Freshly harvested carrot roots with cavity spot symptoms were collected in 2010 from four commercial carrot fields in Michigan, including three in Pentwater County and one in Fremont County, and from four fields in Kern County, CA. The samples were processed immediately after shipment to the laboratory. Carrot roots were washed in running tap water and blotted dry. Tissue from the margin of cavity spot lesions was excised, surface disinfested with $10 \%$ bleach $(0.62 \% \mathrm{NaClO})$ for $3 \mathrm{~min}$, rinsed in sterile distilled water three times, air dried, and cut into about 5-mm (in length) pieces. The tissue was placed on water agar (WA) media amended with carbendazim at $10 \mu \mathrm{g} / \mathrm{ml}$, ampicillin at $50 \mu \mathrm{g} / \mathrm{ml}$, rifampicin at $50 \mu \mathrm{g}$ $/ \mathrm{ml}$, and PCNB at $10 \mu \mathrm{g} / \mathrm{ml}$ (CARP). When mycelial growth from the diseased tissue was observed 3 to 5 days later, hyphal tips were 
transferred to potato dextrose agar (PDA; EMD Chemicals Inc., Gibbstown, NJ) plates amended with CARP for later use. For culture storage, all isolates were cultured on WA for a week, then cut into small mycelial plugs (4 $\mathrm{mm}$ in diameter) and placed in a $15-\mathrm{ml}$ test tube containing $10 \mathrm{ml}$ of sterile distilled water and five sterilized hemp seeds. Cultures were stored at room temperature $\left(22 \pm 1^{\circ} \mathrm{C}\right)$.

The identification of each isolate was determined by morphological characteristics and DNA sequences. For morphological identification, isolates were cultured in sterilized, distilled water with grass (Festuca arundinacea) blades at $22 \pm 1{ }^{\circ} \mathrm{C}$ under fluorescent light, with four replicates per species, as described by Waterhouse (39), and examined based on the key of van der PlaatsNiterink (37). DNA was extracted from the isolates using the following procedure. A mycelial culture plug (4 $\mathrm{mm}$ in diameter) of a Pythium sp. was placed on a disc (8 $\mathrm{mm}$ in diameter) of cellophane (Fisher Scientific Co., Pittsburgh, PA) overlaid on PDACARP, and incubated for 2 to 5 days. When the colony nearly reached the edge of the cellophane, the mycelium on the cellophane disc was scraped off and DNA was extracted using a cetyltrimethylammonium bromide procedure (30). The extracted DNA was used as a template for polymerase chain reaction (PCR) to amplify the rDNA sequences of the internal transcribed spacer (ITS) with primers ITS1 (5'-TCCGTAGGTGAACCTGCGG-3') and ITS4 (5'-TCCTCCGCTTATTGATATGC-3') (43). The thermal cycler setting was an initial denaturation at $94^{\circ} \mathrm{C}$ for $4 \mathrm{~min}$; followed by 36 cycles of $30 \mathrm{~s}$ at $94^{\circ} \mathrm{C}, 30 \mathrm{~s}$ at $58^{\circ} \mathrm{C}$, and $45 \mathrm{~s}$ at $72^{\circ} \mathrm{C}$; and an extension at $72^{\circ} \mathrm{C}$ for $10 \mathrm{~min}$. The PCR products were purified with the IsoPure PCR Purification Kit (Denville Scientific Inc., South Plainfield, NJ) and submitted to Michigan State University Genomics Core Facility for sequencing (ABI 3730xl; Applied Biosystems, Inc. Foster, CA). Both DNA strands of the ITS region were sequenced. The resulting ITS sequences were compared with sequences of closely related species and deposited at the National Center for Biotechnology Information GenBank database.

Virulence of Pythium spp. Harvested carrot roots were inoculated following a previously described method (19). Briefly, mature carrot roots ('Nantindo') were gently washed with tap water, surface sterilized in $10 \%$ bleach for 3 min, rinsed with sterile distilled water three times, and placed on a plastic grid in a plastic box with water below the level of the grid to maintain high humidity. Inoculum consisted of mycelial plugs ( $4 \mathrm{~mm}$ in diameter) cut with a cork borer from the margin of actively growing colonies of Pythium spp. on PDA-CARP. Four mycelial plugs were placed linearly on one carrot root at 3-cm intervals, with the mycelial side facing down on the carrot. On each root, two agar plugs (without mycelia) were used as controls. Three replicate carrot roots were inoculated with each isolate. The inoculated roots were incubated in darkness at room temperature $\left(22 \pm 1^{\circ} \mathrm{C}\right)$. During the incubation period, sterile distilled water was gently sprayed daily over the roots to maintain high moisture. The diameters of the lesions were measured perpendicularly 1 week after inoculation, and the two measurements were averaged. Four independent experiments were conducted for all Pythium spp. but $P$. ultimum, $P$. sylvaticum, and M2-05 were tested two times independently.

Fungicide sensitivity of Pythium spp. Sensitivity to mefenoxam was examined as described (29), with slight modification.
Mefenoxam (47.6\% active ingredient [a.i.], Ridomil Gold EC; Novartis Crop Protection, Inc. Greensboro, NC) was dissolved in dimethyl sulfoxide (DMSO) to make a stock solution $\left(5 \times 10^{4} \mu \mathrm{g}\right.$ a.i./ml). Mefenoxam was added to PDA to final concentrations of 0,10 , or $100 \mu \mathrm{g}$ a.i./ml and final DMSO concentration was adjusted to $0.1 \%$ in PDA. Agar plugs ( $4 \mathrm{~mm}$ in diameter) covered with actively growing mycelium of the different isolates were cut and transferred to plates containing mefenoxam. Triplicate plates were incubated for each isolate per concentration at $22 \pm 1{ }^{\circ} \mathrm{C}$ in the dark. Colony diameters were measured in two perpendicular directions for all plates when the diameters of the controls were at least $30 \mathrm{~mm}$ (the incubation time for this measurement varied depending on the species). The sensitivity to fungicides was expressed as percent inhibition of mycelial growth $[100 \times$ (control treated)/(control $-4 \mathrm{~mm})]$. Isolates were categorized as sensitive when the inhibition was $>60 \%$ with mefenoxam at $10 \mu \mathrm{g}$ a.i. $/ \mathrm{ml}$, highly resistant when the inhibition was $\leq 60 \%$ at $100 \mu \mathrm{g}$ a.i. $/ \mathrm{ml}$; and intermediately resistant when the inhibition was $\leq 60 \%$ at $10 \mu \mathrm{g}$ a.i./ml and $>60 \%$ at $100 \mu \mathrm{g}$ a.i./ml. These thresholds provided excellent resolution of resistant and sensitive isolates in previous studies $(2,29,34)$.

Fungicide-amended agar with various concentrations $(0,0.01$, $0.1,1$, and $10 \mu \mathrm{g}$ a.i. $/ \mathrm{ml}$ ) of fluopicolide (Presidio, 39.5\% a.i.; Valent BioScience Co., Libertyville, IL) or zoxamide ( $80 \%$ a.i.; Gowan Co., Yuma, AZ) were tested in pilot experiments. If the growth of isolates on plates with fungicides at $10 \mu \mathrm{g}$ a.i./ml was more than $50 \%$ of controls, two concentrations of fungicides were used (10 and $50 \mu \mathrm{g}$ a.i. $/ \mathrm{ml})$; if the growth of isolates on plates with fungicides at $10 \mu \mathrm{g}$ a.i./ml was less than $50 \%$ of controls, then five concentrations were used (Table 1). To do this, the fungicide was dissolved in DMSO to make a stock solution $\left(1 \times 10^{4} \mu \mathrm{g}\right.$ a.i. $\left./ \mathrm{ml}\right)$. Cultural plugs of Pythium spp. were transferred to the fungicideamended medium for incubation as described above and three replicate plates for each isolate. The effective concentration of the fungicide to inhibit $50 \%$ of mycelial growth $\left(\mathrm{EC}_{50}\right)$ was determined as described above. All fungicide sensitivity studies were repeated.

Statistical analysis. Data were analyzed with SAS software (version 9.2; SAS Institute Inc. Cary, NC). Procedure GLM was used for an analysis of variance, and Fisher's least significant difference multiple range test was performed for separating means. $\mathrm{EC}_{50}$ values were calculated using regression analysis (using procedure REG) of percentage of growth inhibition against the logarithmic values of fungicide concentrations to the base 10 .

\section{Results}

Isolation and distribution of Pythium spp. In total, $172 P y$ thium-like isolates were obtained from 169 isolations from carrot roots with cavity spot symptoms. In most cases, one species was obtained per lesion. More than one Pythium-like species was obtained from three lesions. All Pythium isolates were classified into nine species based on morphological characteristics and DNA sequences. These included $P$. violae and $P$. dissotocum only from California, and $P$. intermedium, $P$. periplocum, and $P$. sylvaticum only from Michigan (Table 2). P. irregulare, P. sulcatum, and $P$. ultimum were isolated from both California and Michigan (Table 2). The sexual stage of strain M2-05 was not observed due to a single isolate obtained; therefore, the morphological characters

Table 1. Concentrations of fluopicolide and zoxamide used for determining Pythium spp. sensitivity

\begin{tabular}{lll}
\hline & & Concentration $(\boldsymbol{\mu g}$ active ingredient/ml) \\
\cline { 2 - 3 } Pythium spp. & Fluopicolide & \multicolumn{1}{c}{ Zoxamide } \\
\hline Pythium dissotocum & $0,10,50$ & $0,0.03,0.06,0.09,0.18,0.4$ \\
$P$. intermedium & $0,10,50$ & $0,0.05,0.1,0.2,0.4,1$ \\
$P$. irregulare & $0,10,50$ & $0,0.05,0.1,0.5,1,4$ \\
P. sulcatum & $0,10,50$ & $0,0.02,0.04,0.08,0.1,0.4$ \\
P. sylvaticum & $0,0.05,0.1,0.2,0.4,1$ & $0,0.05,0.1,0.2,0.4,1$ \\
$P$. ultimum & $0,0.4,0.6,0.8,1.2,2$ & $0,0.005,0.01,0.025,0.05,0.1$ \\
$P$. violae & $0,0.4,0.6,0.8,1.2,2$ & $0,0.008,0.012,0.024,0.036,0.048$ \\
Strain M2-05 & $0,10,50$ & $0,0.05,0.1,0.2,0.4,1$ \\
\hline
\end{tabular}


were not fully described, and its ITS sequence was $100 \%$ identical to $P$. recalcitrans.

Virulence of Pythium spp. The size of the lesions varied depending on Pythium spp. $(P<0.0001)$, and there was a difference in lesion size between isolates within some species $(P<0.0001)$. The size of the lesions caused by the various isolates also varied by trial. Both $P$. intermedium and $P$. ultimum caused the largest lesions except, in one trial, strain M2-05 and $P$. violae were the least virulent species. Small lesions were observed in two of four trials when carrot was inoculated with $P$. periplocum but $P$. periplocum was reisolated in none of the trials, indicating that it was not pathogenic to carrot (Table 3 ).

Fungicide sensitivity of Pythium spp. Mefenoxam. Most (93\%) isolates of Pythium spp. were sensitive to mefenoxam. However, 3 of 7 Michigan isolates of $P$. intermedium, 5 of 10 Michigan isolates of $P$. sylvaticum, and a single California isolate of $P$. violae had an intermediate level of resistance. Two of eight isolates of $P$. irregulare from California were highly resistant to mefenoxam (Table 4).

Fluopicolide. All isolates of $P$. dissotocum, P. irregulare, $P$. sulcatum, and strain M2-05 were insensitive to fluopicolide $\left(\mathrm{EC}_{50}>\right.$

Table 2. Pythium spp. recovered from carrots with cavity spot symptoms in California and Michigan in 2010 and identified using morphological characteristics and sequence of the internal transcribed sequences regions of rDNA

\begin{tabular}{|c|c|c|c|c|c|c|c|c|c|c|c|}
\hline \multirow[b]{2}{*}{ Locations $^{w}$} & \multirow[b]{2}{*}{$N^{\mathrm{x}}$} & \multicolumn{9}{|c|}{ Number of isolates } & \multirow[b]{2}{*}{ Total } \\
\hline & & $\begin{array}{c}\text { Pythium } \\
\text { dissotocum }\end{array}$ & $\begin{array}{c}P . \\
\text { intermedium }\end{array}$ & $\begin{array}{c}P . \\
\text { irregulare }\end{array}$ & $\begin{array}{c}P . \\
\text { periplocum }\end{array}$ & $\begin{array}{l}\text { Strain } \\
\text { M2-05 }\end{array}$ & $\begin{array}{c}P . \\
\text { sulcatum }\end{array}$ & $\begin{array}{c}P . \\
\text { sylvaticum }\end{array}$ & $\begin{array}{c}P . \\
\text { ultimum }\end{array}$ & $\begin{array}{c}P . \\
\text { violae }\end{array}$ & \\
\hline \multicolumn{12}{|l|}{ California } \\
\hline Kern County $1 *$ & 70 & $3^{\mathrm{y}}$ & $\ldots$ & 4 & $\ldots$ & $\ldots$ & 3 & $\ldots$ & 1 & $61^{\mathrm{y}}$ & 72 \\
\hline Kern County 2 & 46 & 1 & $\ldots$ & 1 & $\ldots$ & $\ldots$ & $\ldots$ & $\ldots$ & $\ldots$ & 44 & 46 \\
\hline Kern County 3 & 17 & $\ldots$ & $\ldots$ & $\ldots$ & $\ldots$ & $\ldots$ & $\ldots$ & $\ldots$ & $\ldots$ & 17 & 17 \\
\hline Kern County 4 & 3 & $\ldots$ & $\ldots$ & $\ldots$ & $\ldots$ & $\ldots$ & $\ldots$ & $\ldots$ & 3 & $\ldots$ & 3 \\
\hline Subtotal & 136 & 4 & $\ldots$ & 5 & $\ldots$ & $\ldots$ & 3 & $\ldots$ & 4 & 122 & 138 \\
\hline \multicolumn{12}{|l|}{ Michigan } \\
\hline Pentwater County $1^{*}$ & 5 & $\ldots$ & $2^{\mathrm{z}}$ & $\ldots$ & $\ldots$ & $\ldots$ & $4^{\mathrm{z}}$ & $\ldots$ & $\ldots$ & $\ldots$ & 6 \\
\hline Pentwater County 2 & 12 & $\ldots$ & $\ldots$ & 1 & $\ldots$ & $\ldots$ & 6 & 5 & $\ldots$ & $\ldots$ & 12 \\
\hline Pentwater County 3 & 3 & $\ldots$ & $\ldots$ & 1 & $\ldots$ & $\ldots$ & 2 & $\ldots$ & $\ldots$ & $\ldots$ & 3 \\
\hline Fremont County & 13 & $\ldots$ & 5 & 1 & 1 & 1 & $\ldots$ & 5 & $\ldots$ & $\ldots$ & 13 \\
\hline Subtotal & 33 & $\ldots$ & 7 & 3 & 1 & 1 & 12 & 10 & $\ldots$ & $\ldots$ & 34 \\
\hline Total & 169 & 4 & 7 & 8 & 1 & 1 & 15 & 10 & 4 & 122 & 172 \\
\hline
\end{tabular}

${ }^{\mathrm{w}}$ Asterisks $(*)$ represent different fields.

$\mathrm{x}$ Number of isolations.

y Two isolations were a combination of $P$. dissotocum and $P$. violae.

${ }^{\mathrm{z}}$ One isolation was a combination of $P$. intermedium and P. sulcatum.

Table 3. Virulence of Pythium spp. on carrot roots as expressed by lesion size

\begin{tabular}{|c|c|c|c|c|c|c|c|c|}
\hline \multirow[b]{2}{*}{ Pythium spp. } & \multicolumn{8}{|c|}{ Lesion diameter $(\mathrm{cm})^{\mathrm{z}}$} \\
\hline & $N$ & Trial 1 & $N$ & Trial 2 & $N$ & Trial 3 & $N$ & Trial 4 \\
\hline Pythium ultimum & 16 & $1.7 \mathrm{a}$ & 16 & $1.9 \mathrm{a}$ & - & - & - & - \\
\hline P. intermedium & 20 & $1.7 \mathrm{a}$ & 28 & $1.3 \mathrm{bc}$ & 24 & $1.6 \mathrm{a}$ & 28 & $1.5 \mathrm{a}$ \\
\hline P. sylvaticum & 40 & $1.6 \mathrm{a}$ & 40 & $1.2 \mathrm{bc}$ & - & - & - & - \\
\hline P. sulcatum & 40 & $1.6 \mathrm{ab}$ & 38 & $1.5 \mathrm{~b}$ & 60 & $0.8 \mathrm{~b}$ & 44 & $1.1 \mathrm{ab}$ \\
\hline$P$. irregulare & 28 & $1.1 \mathrm{~b}$ & 32 & $1.1 \mathrm{c}$ & 32 & $1.0 \mathrm{~b}$ & 28 & $0.8 \mathrm{~b}$ \\
\hline P. dissotocum & 12 & $1.0 \mathrm{~b}$ & 12 & $1.2 \mathrm{c}$ & 8 & $1.0 \mathrm{~b}$ & 6 & $0.7 \mathrm{bc}$ \\
\hline$P$. violae & 48 & $0.6 \mathrm{c}$ & 56 & $0.4 \mathrm{~d}$ & 56 & $0.3 \mathrm{c}$ & 56 & $0.3 \mathrm{c}$ \\
\hline Strain M2-05 & 4 & $0.6 \mathrm{c}$ & 4 & $0.5 \mathrm{~d}$ & - & - & - & - \\
\hline P. periplocum & 4 & $0.0 \mathrm{c}$ & 4 & $0.1 \mathrm{~d}$ & 4 & $0.0 \mathrm{~d}$ & 4 & $0.3 \mathrm{c}$ \\
\hline
\end{tabular}

${ }^{\mathrm{z}}$ Lesion diameters were measured perpendicularly and averaged. Mean values followed by the same letter are not significantly different in the same column according to Fisher's least significant difference method at $\alpha=0.05 . N=$ number of observations and $-=$ not tested.

Table 4. In vitro sensitivity of Pythium spp. to mefenoxam, zoxamide, and fluopicolide

\begin{tabular}{|c|c|c|c|c|c|c|}
\hline \multirow[b]{2}{*}{ Pythium spp. } & \multicolumn{2}{|c|}{ Mefenoxam } & \multicolumn{2}{|c|}{ Fluopicolide } & \multicolumn{2}{|c|}{ Zoxamide } \\
\hline & $N^{\mathrm{x}}$ & Sensitivity ${ }^{y}$ & $N$ & $\mathrm{EC}_{50}(\mu \mathrm{g} \mathrm{a.i.} / \mathrm{ml})^{\mathrm{z}}$ & $N$ & $\mathrm{EC}_{50}(\mu \mathrm{g}$ a.i. $/ \mathrm{ml})$ \\
\hline Pythium dissotocum & 3 & $\mathrm{~S}$ & 4 & $>50$ & 4 & $0.09 \pm 0.03$ \\
\hline \multirow[t]{2}{*}{ P. intermedium } & 4 & $\mathrm{~S}$ & 4 & $<10$ & 7 & $0.08 \pm 0.02$ \\
\hline & 3 & IR & 3 & $>50$ & $\ldots$ & $\ldots$ \\
\hline \multirow[t]{2}{*}{ P. irregulare } & 6 & $\mathrm{~S}$ & 7 & $>50$ & 8 & $0.52 \pm 0.24$ \\
\hline & $2 *$ & HR & $\ldots$ & . & $\ldots$ & $\ldots$ \\
\hline P. sulcatum & 12 & $\mathrm{~S}$ & 15 & $>50$ & 15 & $0.03 \pm 0.02$ \\
\hline \multirow[t]{2}{*}{ P. sylvaticum } & 5 & $\mathrm{~S}$ & 10 & $0.16 \pm 0.06$ & 11 & $0.18 \pm 0.05$ \\
\hline & 5 & IR & & & & \\
\hline P. ultimum & 3 & $\mathrm{~S}$ & 3 & $0.40 \pm 0.05$ & 4 & $0.021 \pm 0.001$ \\
\hline \multirow{2}{*}{ P. violae } & 115 & $\mathrm{~S}$ & 107 & $0.90 \pm 0.27$ & 110 & $0.024 \pm 0.008$ \\
\hline & $1 *$ & IR & $\ldots$ & $\ldots$ & $\ldots$ & \\
\hline Strain M2-05 & 1 & $\mathrm{~S}$ & 1 & $>50$ & 1 & 0.06 \\
\hline
\end{tabular}

${ }^{\mathrm{x}} N=$ number of isolates tested and asterisks $(*)$ indicate that isolates tested were from California.

${ }^{y}$ Sensitivity to mefenoxam was determined by the inhibition of mycelial growth on potato dextrose agar amended with mefenoxam at 10 and $100 \mu \mathrm{g}$ a.i./ml relative to that on the nonamended plate. $\mathrm{S}=$ sensitive, $>60 \%$ on $10 \mu \mathrm{g}$ a.i. $/ \mathrm{ml}$; IR = intermediately resistant, $\leq 60 \%$ on $10 \mu \mathrm{g}$ a.i. $/ \mathrm{ml}$ and $>60 \%$ on $100 \mu \mathrm{g}$ a.i. $/ \mathrm{ml} ;$ and $\mathrm{HR}=$ resistant, $\leq 60 \%$ on $100 \mu \mathrm{g}$ a.i. $/ \mathrm{ml}$.

${ }^{\mathrm{z}} \mathrm{EC}_{50}=$ the effective concentration for $50 \%$ mycelial growth inhibition. 
$50 \mu$ a.i./ml; Table 4). Four of seven isolates of $P$. intermedium were sensitive to fluopicolide, with mycelial growth inhibition $>77 \%$ at $10 \mu \mathrm{g}$ a.i./ml of fluopicolide $\left(\mathrm{EC}_{50}<10 \mu \mathrm{g}\right.$ a.i. $\left./ \mathrm{ml}\right)$; the radial growth of the other three isolates was inhibited $<30 \%$ with fluopicolide at $50 \mu \mathrm{g}$ a.i. $/ \mathrm{ml}\left(\mathrm{EC}_{50}>50 \mu \mathrm{g}\right.$ a.i./ml; Table 4). P. ultimum (mean value of $\mathrm{EC}_{50}=0.4 \mu \mathrm{g}$ a.i. $\left./ \mathrm{ml}\right), P$ sylvaticum $\left(\mathrm{EC}_{50}=\right.$ $0.16 \mu \mathrm{g}$ a.i. $/ \mathrm{ml})$, and $P$. violae $\left(\mathrm{EC}_{50}=0.9 \mu \mathrm{g}\right.$ a.i. $\left./ \mathrm{ml}\right)$ were all sensitive to fluopicolide. The $\mathrm{EC}_{50}$ baseline for 107 isolates of $P$. violae ranged from 0.4 to $1.7 \mu \mathrm{g}$ a.i./ml and was distributed as a unimodal curve (Fig. 1). The results of the two trials were combined.

Zoxamide. All eight Pythium spp. were sensitive to zoxamide, although their sensitivities varied (Table 4). $\mathrm{EC}_{50}$ ranged between $0.52 \mu \mathrm{g}$ a.i. $/ \mathrm{ml}$ for $P$. irregulare and $0.021 \mu \mathrm{g}$ a.i. $/ \mathrm{ml}$ for P. ultimum. Strain M2-05 was not compared because only one isolate was examined. A sensitivity baseline was established using $110 \mathrm{P}$. violae isolates, with $\mathrm{EC}_{50}$ values of 0.01 to $0.06 \mu \mathrm{g}$ a.i./ml, which were distributed in a unimodal curve (Fig. 2).

\section{Discussion}

In this survey of fields in California and Michigan, multiple Pythium spp. were associated with CCS, as suggested by others $(17,20,42)$. The species distribution and frequency, however, were dependent on the location of the fields. $P$. violae was the primary cause of CCS in California, consistent with historical reports $(17,20,42)$. In contrast, $P$. sulcatum, $P$. sylvaticum, and $P$. intermedium accounted for the majority of isolations from CCS in Michigan. $P$. sulcatum and $P$. irregulare were recovered in both California and Michigan. Surprisingly, $P$. violae, $P$. dissotocum, and $P$. ultimum were not recovered in Michigan, and $P$. sylvaticum, $P$. intermedium, and M2-05 were not isolated from California carrot. The different distributions of Pythium spp. associated with CCS may reflect different climates, soil types, or other factors of the two states (6). This is the first report of $P$. dissotocum from carrot in the United States, following a report in the United Kingdom (41) and Canada (2).

The ITS sequence of strain M2-05 was $100 \%$ identical to the ITS sequence of $P$. recalcitrans, reported as a pathogen of grapevine and common beet (25) (GenBank accession number EF195139), but their $\beta$-tubulin sequences were only $87 \%$ identical (X. H. Lu, unpublished). Because this is the first report in carrot, additional studies need to be conducted to determine the taxonomy compared with the known $P$. recalcitrans from other crops. The only isolate of $P$. periplocum examined in this study was not pathogenic to carrot. This species could be an opportunistic organism, because it has been reported as a mycoparasite of Botrytis cinerea (26), Fusarium culmorum (9), and P. ultimum (1). Its ecological role in carrot fields needs to be determined.

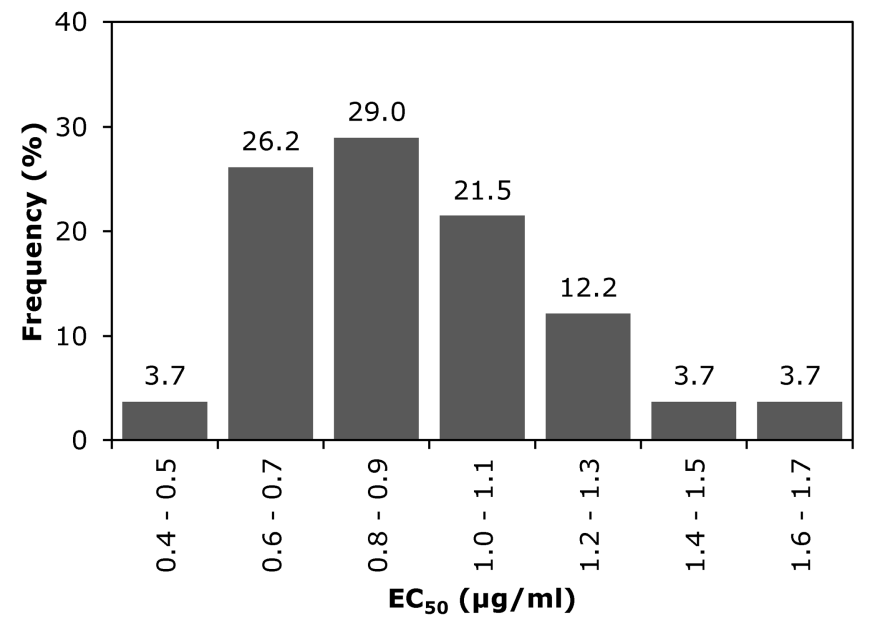

Fig. 1. Distribution of effective concentrations of fluopicolide at which $50 \%$ of mycelial growth was inhibited $\left(\mathrm{EC}_{50}\right)$ for 107 isolates of Pythium violae. The frequency (\%) is the proportion of isolates with $\mathrm{EC}_{50}$ values in the range provided.
Mefenoxam-resistant isolates of $P$. dissotocum, $P$. irregulare, $P$. sylvaticum, $P$. sulcatum, and $P$. ultimum have been reported from carrot $(2,22)$ and other crops $(16,23,24,29,34,35)$. Similarly, two $P$. irregulare isolates from California were highly resistant to mefenoxam, and approximately half of the isolates of $P$. intermedium and $P$. sylvaticum from Michigan were intermediately resistant to mefenoxam. This is the first report of resistance to mefenoxam within a population of $P$. intermedium and $P$. violae, which all were collected from the field. Thus, mefenoxam may not provide satisfactory CCS control in all areas as resistant populations develop. Because of this, new fungicides are urgently needed for the carrot industry. In this study, zoxamide reduced mycelial growth of all Pythium spp. tested, and should be considered a candidate for CCS control as an alternative to mefenoxam.

The sensitivity baselines of zoxamide and fluopicolide for $P$. violae, the most important cause of CCS in California, were established here. These baselines will be helpful for monitoring sensitivity shifts within a population of a pathogen, and may provide useful information on the management of fungicide resistance if fluopicolide and zoxamide are adopted by the carrot industry as expected. Although baseline sensitivities for other Pythium spp. are also important, they could not be established here because few isolates were available. All isolates of $P$. violae, $P$. ultimum, and $P$. sylvaticum were sensitive to fluopicolide, indicating that fluopicolide may be another alternative to mefenoxam, especially in California, where $P$. violae is the primary casual agent of CCS. Because $P$. sulcatum, $P$. irregulare, $P$. dissotocum, and strain M205 are apparently insensitive to fluopicolide, this fungicide probably shouldn't be recommended for use on carrot in Michigan. Among the seven $P$. intermedium isolates, three were sensitive and four were resistant to fluopicolide. Our study on homological analysis of ITS sequences of these isolates showed that the sensitive and insensitive isolates can be classified into two different clusters (X. H. Lu, unpublished), suggesting independent subgroups.

The composition of species of Pythium from carrot in California and Michigan is different; therefore, the choice of fungicides will need to be based on fungicide sensitivities. For example, fluopicolide might be used in California where $P$. violae is the major concern, and zoxamide may be recommended for the management of CCS in both states. Established sensitivity baselines of these fungicides will help monitor fungicide sensitivity shifts in the field.

\section{Acknowledgments}

This research was partially funded through the United States Department of Agriculture Specialty Crop Research Initiative program (NIFA grant number

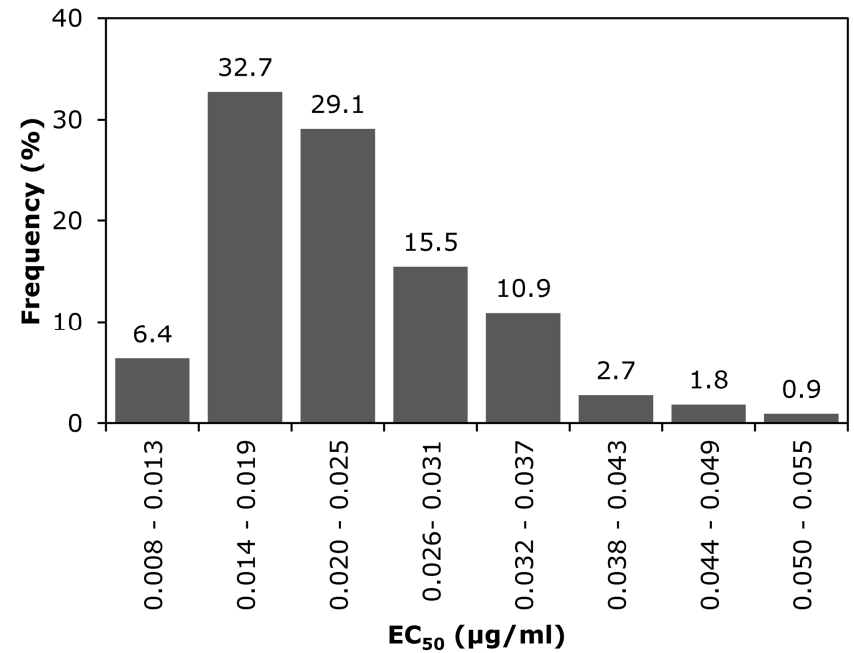

Fig. 2. Distribution of effective concentrations of zoxamide at which $50 \%$ of mycelial growth was inhibited $\left(\mathrm{EC}_{50}\right)$ for 110 isolates of Pythium violae. The frequency $(\%)$ is the proportion of isolates with $\mathrm{EC}_{50}$ values in the range provided. 
2008-51180-04881). We thank N. Goldy for helping to locate fields and contact growers and A. Beslican for laboratory assistance.

\section{Literature Cited}

1. Ali-Shtayeh, M. S., and Saleh, A. S. F. 1999. Isolation of Pythium acanthicum, $P$. oligandrum, and P. periplocum from soil and evaluation of their mycoparasitic activity and biocontrol efficacy against selected phytopathogenic Pythium species. Mycopathologia 145:143-153.

2. Allain-Boule, N., Levesque, C. A., Martinez, C., Belanger, R. R., and Tweddell, R. J. 2004. Identification of Pythium species associated with cavityspot lesions on carrots in eastern Quebec. Can. J. Plant Pathol. 26:365-370.

3. Anonymous. 2011. Page 13 in: Crop Values 2010 Summary. United States Department of Agriculture National Agricultural Statistics Service.

4. Anonymous. 2011. FRAC Code List: Fungicides Sorted by Mode of Action (Including FRAC Code Numbering). Fungicide Resistance Action Committee, Basel, Switzerland.

5. Anonymous. 2011. Page 16 in: Vegetables 2010 Summary (January 2011). United States Department of Agriculture National Agricultural Statistics Service.

6. Broders, K. D., Wallhead, M. W., Austin, G. D., Lipps, P. E., Paul, P. A., Mullen, R. W., and Dorrance, A. E. 2009. Association of soil chemical and physical properties with Pythium species diversity, community composition, and disease incidence. Phytopathology 99:957-967.

7. Cooper, C., Crowther, T., Smith, B. M., Isaac, S., and Collin, H. A. 2006. Assessment of the response of carrot somaclones to Pythium violae, causal agent of cavity spot. Plant Pathol. 55:427-432.

8. Cooper, C., Isaac, S., Jones, M. G., Crowther, T., Smith, B. M., and Collin, H. A. 2004. Morphological and biochemical response of carrots to Pythium violae, causative agent of cavity spot. Physiol. Mol. Plant Pathol. 64:27-35.

9. Davanlou, M., Madsen, A. M., Madsen, C. H., and Hockenhull, J. 1999. Parasitism of macroconidia, chlamydospores and hyphae of Fusarium culmorum by mycoparasitic Pythium species. Plant Pathol. 48:352-359.

10. Davis, R. M., Nunez, J. J., and Guerard, J. P. 1991. If registered, fungicide could reduce cavity spot in carrots. Calif. Agric. 45:29-31.

11. Davison, E. M., and McKay, A. G. 1999. Reduced persistence of metalaxyl in soil associated with its failure to control cavity spot of carrots. Plant Pathol. 48:830-835.

12. Davison, E. M., and McKay, A. G. 2001. Integrated management of $P y$ thium diseases of carrots. Page 88 in: Report of Horticulture Australia Project VG98011.

13. Davison, E. M., and McKay, A. G. 2003. Host range of Pythium sulcatum and the effects of rotation on Pythium diseases of carrots. Australas. Plant Pathol. 32:339-346.

14. El-Tarabily, K. A., Hardy, G., and Sivasithamparam, K. 1997. Effects of host age on development of cavity spot disease of carrots caused by $P y$ thium coloratum in Western Australia. Aust. J. Bot. 45:727-734.

15. Farrar, J. J., Nunez, J. J., and Davis, R. M. 2002. Repeated soil applications of fungicide reduce activity against cavity spot in carrots. Calif. Agric. 56:76-79.

16. Garzon, C. D., Geiser, D. M., and Moorman, G. W. 2005. Amplified fragment length polymorphism analysis and internal transcribed spacer and coxII sequences reveal a species boundary within Pythium irregulare. Phytopathology 95:1489-1498.

17. Guerin, L., Briard, M., and Rouxel, F. 1994. Biochemical characterization of Pythium spp. involved in cavity spot of carrots. Ann. Appl. Biol. 125:255-265.

18. Hao, J., and Davis, M. 2006. Detection of Pythium species causing carrot cavity spot and evaluation of their sensitivity to mefenoxam. (Abstr.) Phytopathology 96:S45.

19. Hermansen, A., Herrero, M. L., Gauslaa, E., Razzaghian, J., Naerstad, R., and Klemsdal, S. S. 2007. Pythium species associated with cavity spot on carrots in Norway. Ann. Appl. Biol. 150:115-121.

20. Hiltunen, L. H., and White, J. G. 2002. Cavity spot of carrot (Daucus carota). Ann. Appl. Biol. 141:201-223.
21. Jacobsohn, R., Zutra, D., Dan, H., and Kelman, Y. 1984. Studies of carrot cavity spot. J. Hortic. Sci. 59:529-535.

22. Martinez, C., Lévesque, C. A., Bélanger, R. R., and Tweddell, R. J. 2005. Evaluation of fungicides for the control of carrot cavity spot. Pest. Manage. Sci. 61:767-771.

23. Moorman, G. W., Kang, S., Geiser, D. M., and Kim, S. H. 2002. Identification and characterization of Pythium species associated with greenhouse floral crops in Pennsylvania. Plant Dis. 86:1227-1231.

24. Moorman, G. W., and Kim, S. H. 2004. Species of Pythium from greenhouses in Pennsylvania exhibit resistance to propamocarb and mefenoxam. Plant Dis. 88:630-632.

25. Moralejo, E., Clemente, A., Descals, E., Belbahri, L., Calmin, G., Lefort, F Spies, C. F. J., and McLeod, A. 2008. Pythium recalcitrans sp. nov. revealed by multigene phylogenetic analysis. Mycologia 100:310-319.

26. Paul, B. 1999. Pythium periplocum, an aggressive mycoparasite of Botrytis cinerea causing the gray mould disease of grape-vine. FEMS Microbiol. Lett. 181:277-280.

27. Perry, D. A., and Harrison, J. G. 1979. Cavity spot of carrots I symptomatology and calcium involvement. Ann. Appl. Biol. 93:101-108.

28. Perry, D. A., and Harrison, J. G. 1979. Cavity spot of carrots II effect of soil conditions and the role of pectolytic anaerobic-bacteria. Ann. Appl. Biol. 93:109-115.

29. Porter, L. D., Hamm, P. B., David, N. L., Gieck, S. L., Miller, J. S., Gundersen, B., and Inglis, D. A. 2009. Metalaxyl-M-resistant Pythium species in potato production areas of the pacific northwest of the USA. Am. J. Potato Res. 86:315-326.

30. Ristaino, J. B., Madritch, M., Trout, C. L., and Parra, G. 1998. PCR amplification of ribosomal DNA for species identification in the plant pathogen genus Phytophthora. Appl. Environ. Microbiol. 64:948-954.

31. Saude, C., Counts, J. W., and Hausbeck, M. K. 2006. A survey of pre- and post-harvest fungal diseases of carrot roots (Daucus carota L.) in Michigan. (Abstr.) Phytopathology 96:S103.

32. Schrandt, J. K., Davis, R. M., and Nunez, J. J. 1994. Host range and influence of nutrition, temperature, and $\mathrm{pH}$ on growth of Pythium violae from carrot. Plant Dis. 78:335-338.

33. Smith, B. M., Crowther, T. C., White, J. G., and Martyn, L. 1997. Screening carrot germplasm for resistance to cavity spot caused by Pythium violae. J. Appl. Genet. 38A:60-70.

34. Taylor, R. J., Salas, B., Secor, G. A., Rivera, V., and Gudmestad, N. C. 2002. Sensitivity of north American isolates of Phytophthora erythroseptica and Pythium ultimum to mefenoxam (metalaxyl). Plant Dis. 86:797-802.

35. Titone, P., Mocioni, M., Garibaldi, A., and Gullino, M. L. 2009. Fungicide failure to control Pythium blight on turf grass in Italy. J. Plant Dis. Prot. 116:55-59.

36. Toquin, V., Barja, F., Sirvan, C., Gamet, S., Latorse, M. P., Zundel, J. L., Schmitt, F., and Beffa, R. 2006. A new mode of action for fluopicolide: modification of the cellular localization of spectrin-like protein. Pflanzenschutz Nachr. Bayer (Ger. Ed.) 59:171-184

37. van der Plaats-Niterink, A. J. 1981. Monograph of the genus Pythium. Stud. Mycol. 21:1-242.

38. Vivoda, E., Davis, R. M., Nunez, J. J., and Guerard, J. P. 1991. Factor affecting the development of cavity spot of carrot. Plant Dis. 75:519-522.

39. Waterhouse, G. M. 1967. Key to Pythium Pringsheim. Mycol. Pap. 109:115.

40. White, J. G. 1986. The association of Pythium spp. with cavity spot and root dieback of carrots. Ann. Appl. Biol. 108:265-273.

41. White, J. G. 1988. Studies on the biology and control of cavity spot of carrots. Ann. Appl. Biol. 113:259-268.

42. White, J. G. 1991. Curing spotty carrots. Grower 115:9-10.

43. White, T. J., Bruns, T., Lee, S., and Taylor, J. 1990. Amplification and direct sequencing of fungal ribosomal RNA genes for phylogenetics. Pages 315 322 in: PCR Protocols. A Guide to Methods and Applications. M. A. Innis, D. H. Gelfand, J. J. Sninsky, and J. G. White, eds. Academic Press, New York. 